\title{
Toxicity and Joint Toxic Action of Some Control Agents on Culex pipiens L. Larvae
}

\author{
Hossam El-Din M. Zahran ${ }^{1}$
}

\begin{abstract}
The present study aimed to assess and to evaluate some of the sustainable and safe measures against Culex pipiens mosquito larva that can be implemented in areas at risk of contacting elephantiasis. The joint toxic action of these control measures was also studied. Data showed that Deltamethrin $\left(\mathrm{LC}_{\mathbf{5 0}}=\mathbf{0 . 0 2 1} \mathrm{ppm}\right)$ was more toxic than Bacillus thurengiensis var. israelensis, diflubenzuron, emamectin benzoate and azadiractin by 2.0, 491.42, 59.0 and 143.8 fold, respectively, after $24 \mathrm{hr}$. Also, after $48 \mathrm{hr}$ Deltamethrin $\left(\mathrm{LC}_{50}=0.004 \mathrm{ppm}\right)$ was 4.0, 1102.5, 25 and 232.5 times more toxic than Vectobac $G$, diflubenzuron, emamectin benzoate and azadiractin, respectively, after 48hr. After $72 \mathrm{hr}$ the toxicity of Deltamethrin $\left(\mathrm{LC}_{50}=\mathbf{0 . 0 0 3}\right.$ ppm) was 3.0, 206.66, 23.33, 246.66 fold more toxic than B.t.i., diflubenzuron, emamectin benzoate and azadiractin, respectively. Toxicity of Beauveria bassiana was very low compared with all the tested control measures with $\mathbf{L C}_{\mathbf{5 0}}$ value $1.85 \mathrm{ml} / \mathrm{L}$ after $72 \mathrm{hr}$ of exposure. Data of joint toxic action revealed that, all mixtures of Beauveria bassiana with diflubenzuron and all mixtures of diflubenzuron with azadiractin resulted in antagonistic effects. Approximately, all other binary mixtures resulted in potentiating effects. The highest potentiating effect was obtained when the mixture of $\mathrm{LC}_{12.5}$ B.t.i. $+\mathrm{LC}_{12.5}$ Deltamethrin was used. Finally, the use of some binary mixtures of the tested control measures can achieve better control, reduce control cost and induce lesser environmental pollution.
\end{abstract}

\section{INTRODUCTION}

Mosquitoes, one of the major arthropods carriers, spread diseases and cause havoc for millions of people in developing countries both among urban and rural populations. The loss in terms of human's lives is irrevocable. It is estimated that every year, at least 600 million people suffer from malaria, filariasis, encephalitis, dengue and recently chikungunya (Ravikiran and Sita Devi 2007). Culex quinquefasciatus (Say) is a major disease transmission vector in Africa as well as in other tropical regions of the world and has been shown to be directly responsible for 80 million annual lymphatic filariasis of which 30 million cases exists in chronic infection. The present proliferation of this disease is not only due to higher number of breeding places in urban area, but also due to increasing resistance of mosquitoes to current commercial insecticides such as organo-chlorides, organophosphates, pyrethroid and carbamates (Das and Amalraj, 1997).

The integrated vector control (IVC), is an ecologically based approach that may involve several complementary interventions used in combination or singly (Lacey and Lacey, 1990). Control measures against filariasis vectors are primarily with conventional adulticides, but the vectors became resistant especially to organophosphorus insecticides due to repeated applications (Juan et al., 1997). So, the use of microbial larvicides such as Bacillus sphaericus (B.s.) and Bacillus thuringensis var. israelensis (B.t.i.) as mosquito larvicides is receiving increasing attention (NielsenLeroux, et al., 1995).

Insect growth regulators (IGRs) also have high levels of activity and efficacy against various species of mosquitoes in a variety of habitats. They are likely to supplementing microbial larvicides, pyrethroids and organophosphorus larvicides (Mulla et al., 1989). A number of benzoylphenylurea (BPU) derivatives have been developed such as triflumuron, which is described as molt inhibitor through interference with cuticle deposition and chitin biosynthesis (Belinato et al., 2009).

Also, insecticidal active ingredients from the neem tree (Azadirachta indica A. Juss) have been recommended in IVC (Parmar, 1993). Neem products are characterized by their effect on growth disrupting (Dua et al., 2009). For dipterous pests, their effects on oviposition, repellence have been reported (Chen et al., 1996). Neem products are known for their fast breakdown of azadirachtin under field conditions (Schmutterer, 1997), so it was used in mixtures for prolongation of its duration of action.

Additionally emamectin benzoate, the semi-synthetic of abamectin which produced by fermentation of Streptomyces avermitilis, is known to have potent toxic activity (Miller et al., 1979) in parasitic disease and was extremely toxic at low concentrations to a wide range of insects including members of the order Diptera (Putter et al., 1981).

The main objective of the present study was to investigate the toxicity of five control agents on the $3^{\text {rd }}$ instar larvae of C.pipiens L. Also, this work was carried

\footnotetext{
${ }^{1}$ Department of Applied Entomology,Faculty of Agriculture

(El- Shatby)Alexandria University, Egypt.

Received March 17, 2010, Accepted March29, 2010
} 
out to study the toxicity of binary mixtures of these control agents aiming to reduce the doses of these insecticides as a primary purpose.

\section{MATERIALS AND METHODS}

\section{The tested materials:}

The following commercially formulations were used: Biofly ${ }^{\circledR}$ (Beauveria bassiana) was obtained form Biotech Manufacture, El-Sadat City. Spore count was done in haemocytometer and was $3 \times 10^{7}$ conidia $/ \mathrm{ml}$. Vectobac $^{\circledR} \mathrm{G}$ (Bacillus thuringiensis var. israelensis 5000 ITU/mg) was provided by Abbott laboratories, North Chicago IL, USA, as a corncob formulation. Dudim $^{\circledR} 4 \% \mathrm{G}$ (diflubenzuron; DML), 1-(4Chlorophenyl)-3-(2,6-difluorobenzoyl) urea was supplied by Duphar B.V., Weesp (Holland). Proclaim ${ }^{\circledR}$ 5\% SG (emamectin benzoate) was supplied by Syngenta. Achook $^{\circledR} 0.15 \%$ EC (azadiractin) was provided by the Egyptian Agricultural development Co. (Egypt) as natural extract. Embrator ${ }^{\circledR} 2.5 \%$ EC (Deltamethrin (DLM)), ((S)- $\alpha$-Cyano-m-phenoxybenzyl (1R,3R)-3-(2,2-dibromovinyl)-2,2dimethylcyclopropane carboxylate) was supplied by KZ Co.(Egypt). Embrator ${ }^{\circledR}$ served as a reference compound for mosquito control based on WHO guidelines.

\section{Insects:}

The used Culex pipiens L. (Diptera: Culicidae) colony was maintained in the laboratory of Medical and Veterinary Insects, Department of Applied Entomology, faculty of Agriculture, Alexandria University, for more than 10 years. Mosquitoes were held at $27 \pm 1{ }^{\circ} \mathrm{C}, 70 \pm 5 \%$ $\mathrm{RH}$, and a photo regime of 14:10 (light:dark) hr. Adults were provided with a $10 \%$ sucrose solution as food source. A pigeon was introduced twice a week to the adults for blood feeding. Larvae were reared in dechlorinated water under the same temperature and light conditions and were fed daily with baby fish food.

\section{Bioassay procedures:}

The larval susceptibility test was conducted according to WHO guidelines (WHO; 1975, 1981). Third instar larvae were used for assessment of the larval susceptibility to the tested compounds. Sufficient numbers of larvae in the $3^{\text {rd }}$ instar were kept in the same breeding water till the test was carried out. Series of concentrations for each compound in addition to control were replicated four times (range of concentrations is shown in Table 1). Lots of 30 larvae were distributed in each replicate (glass beaker), containing $100 \mathrm{ml}$ of water. All the experiments were conducted at $27 \pm 1 \mathrm{C}^{\circ}$ and $75 \pm$ $5 \%$ RH. Mortality counts were carried out after 24, 48 and $72 \mathrm{hr}$ of treatment. Mortality percentages were calculated and corrected according to Abbott, (1925).
The larvae that had pupated during the test were discarded. If more than $10 \%$ of control larvae pupate in the course of the experiment, the test was discarded. The LC-p lines were plotted on log-probit sheets. Values of $\mathrm{LC}_{12.5}, \quad \mathrm{LC}_{25}, \quad \mathrm{LC}_{50}$, Confidence limits and slope functions were calculated and ascertained using Probit program (Finney, 1971).

\section{The joint action of the tested insecticides mixtures:}

To determine the joint toxic action of the tested compounds on C.pipiens $\mathrm{L}$., the calculated $\mathrm{LC}_{12.5}, \mathrm{LC}_{25}$ and $\mathrm{LC}_{50}$ (after $72 \mathrm{hr}$ ) were used alone (to calculate the expected mortalities) and in bi-mixtures. For each treatment, four replicates of 30 larvae/replicate were used. Percent mortalities of larvae were recorded after $72 \mathrm{hr}$ post-treatment.

The joint action of different mixtures in terms of cotoxicity factor (C.F.) was estimated according to Mansour et al., (1966) using the following equati

Co-toxicityfactor $=$ observed\%mortality - expected\%mortality $\times 100$ expected\%mortality

A positive factor of 20 or more is considered potentiation, a negative factor of 20 or more means antagonism and intermediate values between -20 and +20 indicate only additive effect.

\section{Statistical analysis}

Data of bioassay were analyzed using probit program (Finney et al., 1971).

\section{RESULTS AND DISCUSSIONS}

\section{Susceptibility of C. pipiens to some control agents:}

The intension of the statistical analysis proved the insignificant heterogeneity of the results and the goodness of fit of the drawn LC-p lines, as the experimental $(\mathrm{Chi})^{2}$ values were less than those of the tabulated ones at $5 \%$ probability levels. The median lethal concentration $\left(\mathrm{LC}_{50}\right)$ values with their fiducial limits and the slope of the lines were summarized in Table (1). Data have disclosed that Deltamethrin $\left(\mathrm{LC}_{50}=0.021 \mathrm{ppm}\right)$ was more toxic than B.t.i., diflubenzuron, emamectin benzoate and azadiractin by 2.0, 491.42, 59.0 and 143.8 fold, respectively, after 24hr. Also, Deltamethrin $\left(\mathrm{LC}_{50}=0.004 \mathrm{ppm}\right)$ was 4.0, 1102.5, 25 and 232.5 times more toxic than B.t.i., diflubenzuron, Proclaim and azadiractin, respectively, after $48 \mathrm{hr}$. After $72 \mathrm{hr}$ the toxicity of Embrator was 3.0, 206.66, 23.33, 246.66 fold more toxic than B.t.i., diflubenzuron, emamectin benzoate and azadiractin. Toxicity of Beauveria bassiana was very low compared with all the tested control measures with $\mathrm{LC}_{50}$ value $1.85 \mathrm{ml} / \mathrm{L}$ after $72 \mathrm{hr}$ of exposure. 
Table 1. Susceptibility of $3^{\text {rd }}$ instar larvae of $C$.pipiens to different insecticidal compounds

\begin{tabular}{|c|c|c|c|c|}
\hline Compound & $\begin{array}{c}\text { Concentration } \\
\text { range }\end{array}$ & Time (hr) & Slope & $\mathbf{L C}_{50} *$ \\
\hline \multirow{3}{*}{ Beauveria bassiana } & \multirow{3}{*}{$1.5-3.5 \mathrm{ml} / \mathrm{L}$} & 24 & 2.07 & $4.122(3.525-5.365)$ \\
\hline & & 48 & 2.71 & $2.968(2.693-3.325)$ \\
\hline & & 72 & 2.64 & $1.85(1.21-2.72)$ \\
\hline \multirow{3}{*}{ B.t.i. } & \multirow{3}{*}{$0.01-5.0 \mathrm{ppm}$} & 24 & 1.12 & $0.044(0.036-0.054)$ \\
\hline & & 48 & 1.96 & $0.016(0.013-0.019)$ \\
\hline & & 72 & 2.04 & $0.009(0.007-0.012)$ \\
\hline \multirow{3}{*}{ Diflubenzuron } & \multirow{3}{*}{$1-120 \mathrm{ppm}$} & 24 & 1.73 & $10.32(7.41-15.64)$ \\
\hline & & 48 & 1.65 & $4.41(0.246-33.147)$ \\
\hline & & 72 & 1.84 & $0.62(2.674-16.166)$ \\
\hline \multirow{3}{*}{$\begin{array}{c}\text { Emamectin } \\
\text { benzoate }\end{array}$} & \multirow{3}{*}{$0.05-20$ ppm } & 24 & 1.35 & $1.24(1.01-1.51)$ \\
\hline & & 48 & 1.50 & $0.10(0.07-0.14)$ \\
\hline & & 72 & 1.60 & $0.07(0.05-0.09)$ \\
\hline \multirow{3}{*}{ Azadiractin } & \multirow{3}{*}{$0.5-5.0 \mathrm{ppm}$} & 24 & 1.99 & $3.02(2.41-3.74)$ \\
\hline & & 48 & 2.11 & $0.93(0.78-1.08)$ \\
\hline & & 72 & 2.04 & $0.74(0.61-0.90)$ \\
\hline \multirow{3}{*}{ Deltamethrin ** } & \multirow{3}{*}{ 0.001-10 ppm } & 24 & 1.97 & $0.021(0.051-0.028)$ \\
\hline & & 48 & 1.85 & $0.004(0.003-0.006)$ \\
\hline & & 72 & 2.00 & $0.003(0.002-0.005)$ \\
\hline
\end{tabular}

*Concentration required killing $50 \%$ of the larvae.

***eference compound.

The obtained data are strengthened by other previous reports that demonstrate the efficacy of bacterial pesticides. The B.t.i formulation; Vectobac $\mathrm{G}$ was found to be effective in reducing larval populations of Culex pipiens and Aedes aegypti at the $0.01 \mathrm{mg} / \mathrm{liter}$ level and susceptibility varied according to different species and strains of mosquito larvae (Chui et al., 1993).

Regarding Beauveria bassiana, larvae may have rejected the spore mass as food most likely because of large clump size and the density of the mass made spore attachment avoidable (Prasad and Veerwal, 2010). After inoculation with Beauveria bassiana, fungal isolation, the hypha penetrated the integument inside the whole body cavities then reached all cells like fat, neural and muscle tissues and damage them. Even though, Beauveria bassiana spores act as midgut toxins, when applied over the water surface they are readily available to the larvae (Hajek and Leger, 1994).

The high efficiency of microbial agents is due to its specificity in action where its toxic protein molecules (delta-endotoxins; 25-KDa proteins in case of B.t.i.) attach to the accessible mosquito midgut cell membrane receptor, most likely phospholipids and glycoconjugates in a progressive and irreversible manner to generate small pores. The creation of these spores will lead to

colloid-osmotic lysis, i.e. cell swelling and eventual lysis (Chilcott, et al., 1990).

Therefore, the most toxic tested formulations; B.t.i. and deltamethrin (reference compound) are recommended for control of C.pipiens, however the hazardous effect of classical chemical insecticide; deltamethrin on the beneficial insects and the surrounding ecosystem should be taken into consideration if it will be applied in the field on large scale. The obtained data indicated that IGR Dudim (diflubenzuron) proved to have a delayed effect on $C$. pipiens larvae for the first $72 \mathrm{hr}$ after treatment. The obtained findings are in agreement with a previous study (Kawada et al., 1993) that discussed the larvicidal efficacy of IGR Dudim (diflubenzuron) on anopheline mosquitoes (A. sergenti, gambiae, albimanus). In all species, no cross resistance between IGRs and the other kinds of insecticides, such as organophosphate, organochlorine, carbamate and pyrethroid, was observed. The mosquitocidal effects observed in triflumuron-treated larvae were similar to those commonly induced by diflubenzuron (Seccacini, et al., 2008).

Achook $(0.15 \%$ azadirachtin) was found to have larvicidal activity $\left(\mathrm{LC}_{50}=3.02 \mathrm{ppm}\right.$ after $24 \mathrm{hr}$ posttreatment) on C. pipiens larvae. The larvicidal effect of 
Table 2.The joint-action of different bi-mixtures of the tested compounds against the $3^{\text {rd }}$ instar larvae of $C$.pipiens after $72 \mathrm{hr}$ post-treatment

\begin{tabular}{|c|c|c|c|c|}
\hline \multirow{2}{*}{ LC levels ${ }^{a}$ (Bi-mixture) } & \multicolumn{2}{|c|}{$\%$ mortality } & \multirow{2}{*}{ C.F. ${ }^{\mathbf{b}}$} & \multirow{2}{*}{ Joint action ${ }^{c}$} \\
\hline & Expected & Observed & & \\
\hline $\mathrm{LC}_{12.5}$ Beauveria bassiana $+\mathrm{LC}_{25}$ Diflubenzuron & 37.50 & 19.33 & -48.45 & A \\
\hline $\mathrm{LC}_{12.5}$ Beauveria bassiana $+\mathrm{LC}_{50}$ Diflubenzuron & 62.50 & 23.00 & -63.20 & A \\
\hline $\mathrm{LC}_{25}$ Beauveria bassiana $+\mathrm{LC}_{25}$ Diflubenzuron & 50.00 & 21.67 & -56.66 & A \\
\hline $\mathrm{LC}_{25}$ Beauveria bassiana $+\mathrm{LC}_{50}$ Diflubenzuron & 75.00 & 29.00 & -61.33 & A \\
\hline $\mathrm{LC}_{12.5}$ Beauveria bassiana $+\mathrm{LC}_{12.5}$ Azadiractin & 25.00 & 59.67 & 138.68 & $\mathrm{P}$ \\
\hline $\mathrm{LC}_{12.5}$ Beauveria bassiana $+\mathrm{LC}_{25}$ Azadiractin & 37.50 & 68.00 & 81.33 & $\mathrm{P}$ \\
\hline $\mathrm{LC}_{25}$ Beauveria bassiana $+\mathrm{LC}_{12.5}$ Azadiractin & 37.50 & 60.00 & 60.88 & $\mathrm{P}$ \\
\hline $\mathrm{LC}_{25}$ Beauveria bassiana $+\mathrm{LC}_{25}$ Azadiractin & 50.00 & 85.67 & 71.34 & $\mathrm{P}$ \\
\hline $\mathrm{LC}_{12.5}$ Beauveria bassiana $+\mathrm{LC}_{12.5}$ Deltamethrin & 25.00 & 71.33 & 185.32 & $\mathrm{P}$ \\
\hline $\mathrm{LC}_{12.5}$ Beauveria bassiana $+\mathrm{LC}_{25}$ Deltamethrin & 37.50 & 75.00 & 100 & $\mathrm{P}$ \\
\hline $\mathrm{LC}_{25}$ Beauveria bassiana $+\mathrm{LC}_{12.5}$ Deltamethrin & 37.50 & 72.67 & 93.78 & $\mathrm{P}$ \\
\hline $\mathrm{LC}_{25}$ Beauveria bassiana $+\mathrm{LC}_{25}$ Deltamethrin & 50.00 & 100 & 100 & $\mathrm{P}$ \\
\hline $\mathrm{LC}_{12.5}$ Beauveria bassiana $+\mathrm{LC}_{12.5}$ Emamectin benzoate & 25.00 & 52.33 & 109.32 & $\mathrm{P}$ \\
\hline $\mathrm{LC}_{12.5}$ Beauveria bassiana $+\mathrm{LC}_{25}$ Emamectin benzoate & 37.50 & 59.00 & 57.33 & $\mathrm{P}$ \\
\hline $\mathrm{LC}_{25}$ Beauveria bassiana $+\mathrm{LC}_{12.5}$ Emamectin benzoate & 37.50 & 54.67 & 45.78 & $\mathrm{P}$ \\
\hline $\mathrm{LC}_{25}$ Beauveria bassiana $+\mathrm{LC}_{25}$ Emamectin benzoate & 50 & 78.33 & 56.66 & $\mathrm{P}$ \\
\hline $\mathrm{LC}_{12.5}$ B.t.i. $+\mathrm{LC}_{25}$ Diflubenzuron & 37.50 & 50.00 & 33.33 & $\mathrm{P}$ \\
\hline $\mathrm{LC}_{12.5}$ B.t.i. $+\mathrm{LC}_{50}$ Diflubenzuron & 62.50 & 33.33 & -46.67 & A \\
\hline $\mathrm{LC}_{25}$ B.t.i. $+\mathrm{LC}_{25}$ Diflubenzuron & 50.00 & 43.33 & -13.34 & $\mathrm{AD}$ \\
\hline $\mathrm{LC}_{25}$ B.t.i. $+\mathrm{LC}_{50}$ Diflubenzuron & 75.00 & 56.67 & -24.44 & A \\
\hline $\mathrm{LC}_{12.5}$ B.t.i. $+\mathrm{LC}_{12.5}$ Azadiractin & 25.00 & 63.33 & 153.32 & $\mathrm{P}$ \\
\hline $\mathrm{LC}_{12.5}$ B.t.i. $+\mathrm{LC}_{25}$ Azadiractin & 37.50 & 68.67 & 83.12 & $\mathrm{P}$ \\
\hline $\mathrm{LC}_{25}$ B.t.i. $+\mathrm{LC}_{12.5}$ Azadiractin & 37.50 & 87.70 & 133.90 & $\mathrm{P}$ \\
\hline $\mathrm{LC}_{25}$ B.t.i. $+\mathrm{LC}_{25}$ Azadiractin & 50.00 & 89.00 & 78.00 & $\mathrm{P}$ \\
\hline $\mathrm{LC}_{12.5}$ B.t.i. $+\mathrm{LC}_{12.5}$ Deltamethrin & 25.00 & 89.33 & 257.20 & $\mathrm{P}$ \\
\hline $\mathrm{LC}_{12.5}$ B.t.i. $+\mathrm{LC}_{25}$ Deltamethrin & 37.50 & 100 & 166.7 & $\mathrm{P}$ \\
\hline $\mathrm{LC}_{25}$ B.t.i. $+\mathrm{LC}_{12.5}$ Deltamethrin & 37.50 & 94.00 & 150.70 & $\mathrm{P}$ \\
\hline $\mathrm{LC}_{25}$ B.t.i. $+\mathrm{LC}_{25}$ Deltamethrin & 50.00 & 100 & 100 & $\mathrm{P}$ \\
\hline $\mathrm{LC}_{12.5}$ B.t.i. $+\mathrm{LC}_{12.5}$ Emamectin benzoate & 25.50 & 58.00 & 132 & $\mathrm{P}$ \\
\hline $\mathrm{LC}_{12.5}$ B.t.i. $+\mathrm{LC}_{25}$ Emamectin benzoate & 37.50 & 81.67 & 117.80 & $\mathrm{P}$ \\
\hline $\mathrm{LC}_{25}$ B.t.i. $+\mathrm{LC}_{12.5}$ Emamectin benzoate & 37.50 & 67.33 & 79.50 & $P$ \\
\hline $\mathrm{LC}_{25}$ B.t.i. $+\mathrm{LC}_{25}$ Emamectin benzoate & 50.00 & 82.00 & 64.00 & $\mathrm{P}$ \\
\hline $\mathrm{LC}_{25}$ diflubenzuron $+\mathrm{LC}_{12.5}$ Deltamethrin & 37.50 & 73.33 & 95.50 & $\mathrm{P}$ \\
\hline $\mathrm{LC}_{25}$ diflubenzuron $+\mathrm{LC}_{25}$ Deltamethrin & 50.00 & 90.00 & 80.00 & $\mathrm{P}$ \\
\hline $\mathrm{LC}_{50}$ diflubenzuron $+\mathrm{LC}_{12.5}$ Deltamethrin & 62.50 & 60.00 & -4.00 & $\mathrm{AD}$ \\
\hline $\mathrm{LC}_{50}$ diflubenzuron $+\mathrm{LC}_{25}$ Deltamethrin & 75.00 & 89.00 & 18.66 & A \\
\hline $\mathrm{LC}_{25}$ diflubenzuron $+\mathrm{LC}_{12.5}$ Emamectin benzoate & 37.50 & 96.67 & 157.80 & $\mathrm{P}$ \\
\hline $\mathrm{LC}_{25}$ diflubenzuron $+\mathrm{LC}_{25}$ Emamectin benzoate & 50.00 & 100 & 100 & $\mathrm{P}$ \\
\hline $\mathrm{LC}_{50}$ diflubenzuron $+\mathrm{LC}_{12.5}$ Emamectin benzoate & 62.50 & 53.33 & 147 & $\mathrm{P}$ \\
\hline $\mathrm{LC}_{50}$ diflubenzuron $+\mathrm{LC}_{25}$ emamectin benzoate & 75.00 & 100.00 & 33.33 & $\mathrm{P}$ \\
\hline $\mathrm{LC}_{25}$ diflubenzuron $+\mathrm{LC}_{12.5}$ Azadiractin & 37.50 & 0.0 & -100 & A \\
\hline $\mathrm{LC}_{25}$ diflubenzuron $+\mathrm{LC}_{25}$ Azadiractin & 50.00 & 0.0 & -100 & A \\
\hline $\mathrm{LC}_{50}$ diflubenzuron $+\mathrm{LC}_{12.5}$ Azadiractin & 67.50 & 0.0 & -100 & A \\
\hline $\mathrm{LC}_{50}$ diflubenzuron $+\mathrm{LC}_{25}$ Azadiractin & 75.00 & 0.0 & -100 & $\mathrm{~A}$ \\
\hline $\mathrm{LC}_{12.5}$ azadiractin $+\mathrm{LC}_{12.5}$ Deltamethrin & 25.00 & 96.00 & 284 & $\mathrm{P}$ \\
\hline $\mathrm{LC}_{12.5}$ azadiractin $+\mathrm{LC}_{25}$ Deltamethrin & 37.50 & 100 & 166.70 & $\mathrm{P}$ \\
\hline $\mathrm{LC}_{25}$ azadiractin $+\mathrm{LC}_{12.5}$ Deltamethrin & 37.50 & 97.67 & 160.50 & $\mathrm{P}$ \\
\hline $\mathrm{LC}_{25}$ azadiractin $+\mathrm{LC}_{25}$ Deltamethrin & 50.00 & 100 & 100 & $\mathrm{P}$ \\
\hline
\end{tabular}

LC levels $=$ concentration of the tested compounds C.F. $=$ Cotoxicity factor

${ }^{\mathrm{c}}$ Joint action: $\mathrm{P}=$ Potentiator $\mathrm{A}=$ Antagonistic $\mathrm{AD}=$ Additive 
neem increased by time. Neem products are known for their fast breakdown of the active component under field conditions (Schmutterer, 1997), so it is often used in mixtures for prolongation of its duration of action.

Most of literatures suggested that the wide spread use of proclaim in veterinary and human medicine showed a highly potential larvicidal effect with unrecognized mode of action on mosquito populations. Recently, Foley et al., (2000) reported that a high mortality was observed in Anopheles farauti mosquitoes fed on blood of volunteers treated with ivermectin (22,23 dihydroavermectin B1; $250 \mu \mathrm{g})$. Ivermectin treatment of animals could have an important role in malaria control when A. farauti is the vector. In most ivermectin-treated Aedes aegypti females $(0.1 \mu \mathrm{g} / \mathrm{mL})$ within $1 \mathrm{hr}$ after ingestion of blood containing this chemical, uncoordinated movements, paralysis and death were observed (Mahmood et al., 1991). The most striking effect of ivermectin on A. aegypti at this dosage was on ovarian development.

It is worthy to mention that there is seasonal concentration and expansion of the elephantiasis vector population, where during winter the vector population is localized and the larval cycle of the mosquitoes increases from approximately 8 days in summer to about 44 days during winter. Consequently, the production of adult mosquitoes is reduced and the population becomes concentrated in the larval stages. Hence, larval breeding sites during winter could be targeted for supplementary control measures, thereby enhancing the overall control efforts (Abd-Allah et al.,2002).

\section{Joint action of some control agents mixtures in $C$. pipiens}

In order to raise the efficiency of the tested control agents and improve their characters, in current study, we have tested the joint toxic action of them at different concentrations which is shown in Table (2). It is clear that, all mixtures of Beauveria bassiana with diflubenzuron and all mixtures of diflubenzuron with azadiractin resulted in antagonistic effects. On the other hand, all other binary mixtures resulted in potentiating effects. The highest potentiating effect was obtained when the mixture of $\mathrm{LC}_{12.5}$ B.t.i. $+\mathrm{LC}_{12.5}$ Deltamethrin was used. This means that the dosages of these compounds can be reduced when they are used in mixtures. The strong synergistic effect observed by Darriet and Corbel (2006) between pyriproxyfen and spinosad allows a reduction in both pyriproxyfen and spinosad amounts by 5 and 9 fold to kill almost $100 \%$ mosquitoes.
Although the current study proved the larvicidal potency of the tested compounds especially when used in mixtures, the choice of target-specific, environmentally safe and economically cost-effective combinations will be the end point determinant in IVC programs and strategies for mosquito control. Further complementary testing under semi-field and full field conditions are needed to specify the strategy that can be implemented in risky areas.

\section{REFERENCES}

Abbott, W.S. (1925). A method for computing the effectiveness of an insecticide. J.Econ.Entomol. 18:265267.

Abd-Allah, S.; Al-Eryan, M. and Macklad, F. (2002). Efficacy of Different unconventional pesticides on Anopheles sergenti. In proceeding of the first Conf. of the central Agric. Pesticide Lab.,3-5 Sep. Cairo, Egypt. pp: 771-786.

Belinato, T.A.; Martins, A.J.; Lima, J.B.P.; Lima-camara, T.N.; Peixoto, A.A. and Valle, D. 2009. Effect of the chitin synthesis inhibitor triflumuron on the development, viability and reproduction of Aedes aegypti. Mem. Inst. Oswaldo Cruz, Riode Janeiro, vol, 104(1): 43-47.

Chen, C.C.; Dong, Y.J.; Cheng, L.L. and Hou, R.F.(1996). Deterrent effect of neem seed kernel extract on oviposition of the oriental fruit fly.J.Econ. Entomol. 89:462-466.

Chilcott, C.N.; Knowles, B.H.;Ellar, D.J. and Drobniewski, F.A.(1990). Mechanism of action of Bacillus thuringiensis israelensis parasporal body. Bacterial control of mosquitoes \& black flies: biochemistry, genetics \& application of Bacillus thuringiensis israelensis and Bacillus sphaericus (de Barjac, H. and Sutherland, D.J.; eds), p.45-65; New Brunswick, New Jersy, USA; Rutgers University press.

Chui, V.W.D.; Koo, C.W.; Lo, W.M.; Qui-XuJia and Qiu, X.J. (1993). Laboratory evaluation of Vectobac-12AS and teflubenzuron against Culex pipiens and Aedes mosquito larvae under different physical conditions. EnvironmentInternational. 19(2): 193-202.

Darriet, F. and Corbel, V. (2006). Laboratory evaluation of pyriproxyfen and spinosad, alone and in combination, against Aedes aegypti larvae. J. Med. Entomol., 43: 11901194.

Das, P.K. and Amalraj, D.1997. Biological control of malaria vectors. Indian J. of Med. Res. 106: 174.

Dua, V.K.; Pandey, A.C.; Raghavendra, K.; Gupta, A.; Sharma, T. and Dash, A.P. 2009. Larvicidal activity of neem oil (Azadirachta indica) formulation against mosquitoes. Malar. J. (8):124.

Finney, D.J. (1971). Probit Analysis. $3^{\text {rd }}$ edition. Cambridge University press. Cambridge, 318 pp.

Foley, D.H.; Bryan, J.H. and Lawrence, G.W.(2000). The potential of Ivermectin to control the malaria vector Anopheles farauti. Trans. R. Soc. Med. Hyg. 94(6): 625628. 
Hajek, A.E.; and Leger, G.P.St. (1994). Interaction between fungal pathogens and insect hosts. Annu. Rev. Entomol. 39:293-322.

Juan, B.; Rodriquez, M.; Soca, A.; Pasteur, N. and Raymond, M. (1997). Cross-resistance to pyrethroid and organophosphorus insectecides in the Southern house mosquito (Diptera: Culicidae) from Cuba. Entomological society of America 244-246.

Kawada, H.;Shano, Y.; Ito, T. and Abo, Y.(1993). Laboratory evaluation of insect growth regulators against several species of Anopheline mosquitoes. Jap. J. Santi. Zool. 44(4):349-353.

Lacey, L.A. and Lacey, C.M.(1990). The medical importance of rice land mosquitoes and their control using alternative to chemical insecticides. J. Am. Mosq. Cont. Assoc. (suppl 2): 1-93.

Mahmood, F.; Walters, L.L.; Guzman, H. and Tesh, R.B. (1991). Effect of ivermectin on the ovarian development of Aedes aegyti (Diptera: Culicidae). J.Med. Entomol. 28(5): 701-707.

Mansour, N.A.; Eldefrawy, M.E.; Toppozada, A. and Zeid (1966). Potentiation and antagonism of organophosphorous and carbamate insecticides. J. Econ. Entomol. 307-311.

Miller, T.W.; Chaiet, L.; Cole, D.J. and Putter, I.(1979). Avermectins, a new family of potent anthelmintic agents:isolation and chromatographic properties. Antimicrob. Agents Chem-Mother. 15:368-371.

Mulla, M.S.; Darwazh, A.H. and Schreiber, T.E.(1989). Impact of new insect growth regulators and their formulations on mosquito larval development in impoundment and floodwater habitats. J. Am. Mosq. Cont. Assoc. 5:15-20.
Nielsen-Leroux, C.; Charles, J.F.; Thiery, I. and Georghiou, G.P.(1995). Resistance in laboratory population of Culex quinquefasciatus (Diptera: Culicidae) to Bacillus sphaericus binary toxin is due to a change in the receptor on midgut-brush border membranes. Eur. J. Biochem. 228:206-210.

Parmar, B.S.(1993). Scope of botanical pesticides in integrated pest management. J. Insect. Sci. 6(1): 15-20.

Prasad, A. and Veerwal, B.(2010). Biotoxicity of entomopathogenic fungus Beauveria bassiana (Balsamo) Vuillemin, against early larval instars of anopheline mosquitoes. J.of herbal medicine \& toxicology. 4(2):181188.

Putter, I.; MacConnel, J.G.; Priser, F.A.; Haidri, A.A.; Ristich, S.S. and Dybas, R.A. (1981). Avermectins: novel insecticides, acaricides and nematicides from a soil microorganism. Experientia 37:963-964.

Ravikiran, S. and Sita Devi, P. 2007. Evolution of mosquitocidal activity of essential oil and sesquiter pernes from leaves of chloroxylon swietenia DC. Parasitol. Research, 101: 413-418.

Schmutterer, H. (1997). Potential of Azadirachtin-containing pesticides for integrated pest control in developing and industrialized countries. J. insect Physiol. 34(7): 713-719.

Seccacini E., Lucia, A.; Harburguer, L.; Zerba, E.; Licastro, S. and Masuh, H.(2008). Effectiveness of Pyriproxyfen and Diflubenzuron formulations as larvicides against Aedes aegypti. J.Am. Mosq. Cont. Assoc. 24(3) 398-403.

World Health Organization (1975). Manual on practical entomology in malaria. Part II (Meth.\& Tech.) Geneva, Swizerland.

World Health Organization (1981). Report on Informal consultation on standardization of Bacillus thuringiensis H-14. TDR/BCV/BTH-14/811,WHO/VBC/81-828. 


\section{الملخص العربي}

السمية والتأثير السام المشترك لبعض المواد المستخدمة في مكافحة يرقات بعوض الكيولكس بيبينز حسام الدين مجدي زهران

وكانت سمية الـBeauveria bassiana منخفضة جـدا مقارنة

بباقي المركبات المختبرة حيث كانت قيمة الـ LC الخ الخاصة به تساوي 1.85 مل/لتر و ذلك بعد 72 ساعة من المعاملة.

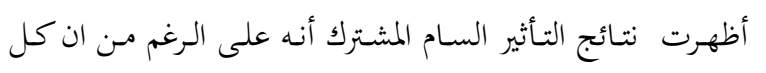

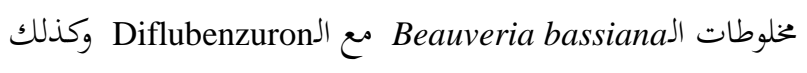

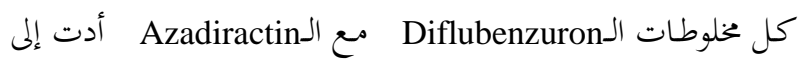
ظهـور تأثـير تثبـيط للفعـل الإبادي الا ان كـل المخلوطـات الثنائيسة الأخرى أدت إلى ظهور تنشيط للفعل الإبادي.

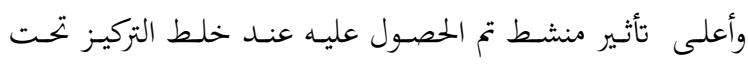

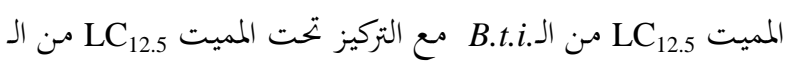

.Deltamethrin

وأخيرا فإن إستخدام المخلوطات الثنائية من المركبات المختبرة يمكن

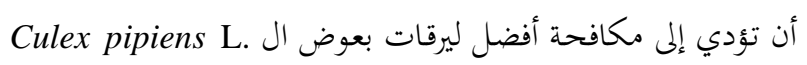
كما أفا تقلل تكاليف المكافحة و تقلل من تلوث البيئة.
تهـدف هـذه الدراسة إلى تقييم مجموعة مـن المركبات الآمنـة ضـد

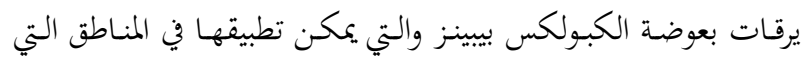

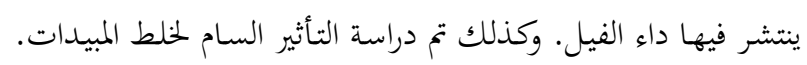

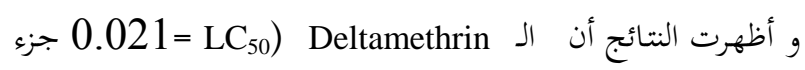

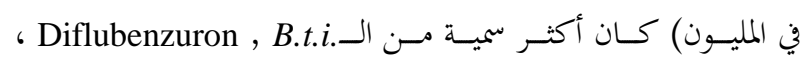
، Azadiractin ، Emamectin benzoate 59 ، 143.8 ضـعفاً على الترتيـب بعـد 24 سـاعة. كمـا أن الـ 0.004=LC Deltamethrin

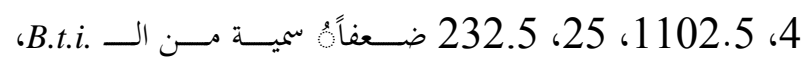
Azadiractin ،Emamectin benzoate ،Diflubenzuron الترتيب وذلك بعد 48 ساعة من بدء المعاملة.

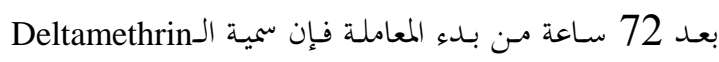

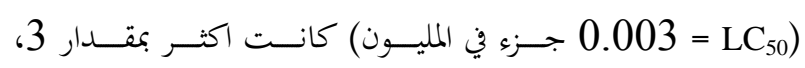

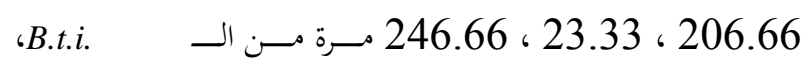
.Azadiractin،Emamectin benzoate ‘Diflubenzuron 